\title{
Peer Pressure and Socioeconomic Status as Predictors of Student's Attitude to Examination Malpractice in
} Nigeria

\author{
Grace Nwamaka Okorodudu ${ }^{1, *}$ \\ ${ }^{1}$ Institute of Education, Delta State University, Abraka, Nigeria \\ *Correspondence: Tel: 234-803-583-9000 E-mail: okororich@yahoo.com; \\ okorograce@gmail.com
}

Received: October 15, 2012 Accepted: December 4, 2012 Published: January 13, 2013

doi:10.5296/ije.v5i1.2532 URL: http://dx.doi.org/10.5296/ije.v5i1.2532

\begin{abstract}
Examination malpractice has remained a serious challenge to public examinations. The paper examined the influence of peer pressure and socioeconomic status and student's attitude toward examination malpractice. A survey design was employed using a sample size of 1000 Junior Secondary two students. Questionnaire was used to elicit the right responses on peer pressure and students attitude toward examination malpractice. Simple regression statistics was also used to establish the influence of peer pressure on students' attitude towards examination malpractice. The result showed that peer pressure significantly predicts students' attitude to examination malpractice. The paper suggested some measures counsellors can use to reduce influence of peer pressure on students' attitude toward examination malpractice.
\end{abstract}

Keywords: peer pressure; socio economic status; attitude to examination malpractice 


\section{Introduction}

Recently, the degree of secondary school students' involvement in examination malpractice has become increasingly alarming, problematic and threatening to the well-being of Nigeria educational system (Judy and Nelson, 2002). Edukugho (2006) describes conduct of examination in secondary education in Nigeria as a huge mockery of the whole exercise. He further stressed on some factors not making the conduct of examination worthwhile as massive leakage of question paper, reckless impersonation in the examination centre, machineries hired by registered students to write examination for them, desperation of school proprietors, unethical method to cheat, bribing examination officials, parents buying leaked 'live' papers in advance for their child before the commencement of the examination and a host of others. Parents go to the extent of bribing their way to ensure their ward get unearned grade while teachers encourages examination malpractices is because they lack the zeal to work but want to be praised for job not done (Olushola, 2006).

Ibukun and Oyewole (2011), examine examination malpractices in Nigerian schools: environmental influences and management strategies and found that examination malpractices is one of the greatest social menace and canker worms that has eaten deep into Nigeria Educational system. The growing rate of this academic dishonesty and fraudulence is alarming. They citing the daily time of Nigeria July4, 1995 listed various forms of examination dishonesty to include: various form of collusion, spying, mutual exchange of materials, impersonation, assault of invigilators and hiring of thugs to disrupt examinations etc.

They claim that examination supervision is today a hazardous assignment in Nigeria measures of curbing this ill in the society were also suggested by them as follows:

(1) There should be consistent and higher investment and funding of the educational system.

(2) Provision of material resources and equipment in all schools etc.

Similarly, Abdulrazaq and Aminullahi (2008) found that examination malpractice is one of the greatest problems undermining the foundation of educational practice in Nigeria. They further stated that the magnitude of the problem and the dangers of the phenomenon have been identified by stake holders as national malady that required drastic solution. Examinations and standards, an arm of the Delta State Ministry of Education has this to say about the conduct of both internal and external examinations in Nigeria educational system: "so examination fraud has become the order of the day in the school with the active support of a virile adult population.

For many years we have resigned to fate and allowed it to take a firm hold on our school system, and we managed to continue to produce graduates at different academic levels albeit half-baked. The virtue of hard work and diligence as emphasised in the National policy on education as respect for dignity of labour as means of achieving success (NPE, 2008) is dead and kept in the mortuary. It will take the supernatural hands of God to bring it to live again. Then where do we go from here when children of today are adults of tomorrow to manage every sector of Nigeria economy? A lot of work has been done on the causes, forms and 
effects of examination malpractice, but few works has been done on preventive measures. Jekayinfa (undated) noted that the development of a nation largely depends in the types of values that are cherished, vigorously pursued and applied by majority of us citizens. Although values vary from place to place, time and space there are some universal value accepted in the societies e.g. honesty, hard work, justices and patriotism. To him, these values have been greatly eroded and some social vices emerged which threatened the cherished values. Paramount, among them is the examination malpractice. He presented a list of causes to include the peer pressure.

It is against this background that this paper examined peer pressure and socio-economic status as predators of students' attitude to examination malpractice in Nigeria.

\section{Literature Review}

Examination malpractice is one of widespread vices among secondary school students. The fraudulent act is seriously ravaging our educational system. Edukugbo (2006) observed that the grip of a devastating examination fraud has greatly ridiculed the products and certificate churned out. Ivor (2008) lamentably claimed that there is decline in the standard of education, little or no learning measure of knowledge and ability to match the certificates possessed by the students. This has taken alarming, threatening and frightening dimensions among secondary school students in Nigeria. Maheshwari (2011) described the vices as termites destroying educational set up. He noted that the process of examination among students in Indian schools and colleges has become a "contemporary shame". He described this menace as becoming endemic ugly scenario in the educational system. Students are involved because they want success; parents are involved because they want good grade for their wards; teachers and others are involved because of the financial, material and other intangible gains. This particular phenomenon is caused by factors beyond our control.

Theoretically, Wikipedia(2010) reported the views of structural functionalism. The theory stated that individuals commit crimes for the good of an individual group, for self due to or justified by lack of ties or because the societal norms that place the individual in check no longer have power due to society's corruption. It is an unfortunate event that the adults who supposed to have put in check, the examination malpractice are all supporting and promoting it (example; parents, principals, teachers, examination officials, security agents and a host others( Ministry of Education, 2006). They do these for a token (financial reward) or for the good of the students or because the societal norms that place the individual in check no longer have power.

Wikipedia (2010) also stressed Robert K. Merton theory which goes further to state that anomie is the state in which social goals and the legitimate means of achieving them do not correspond. Merton also stated that an individual's response to societal expectations and means by which the individual pursued those goals were useful in understanding deviance. Secondary school students are no longer committed to their academic pursuit because they believe that they can always receive assistance in the examinations. For instance a student 
have this to say " $i$ got money from my parents when i learnt about leakage of questions, because i don't want to be left out, i want to score excellent grades also like my mates who had seen the papers, so as to score much as them''(Edukugho, 2006).

The incidence of examination malpractice has reached frightening dimension. Parents give their children money to buy leaked papers ahead of time. The students (lazy and indolent) prepare answers to questions in advance or other adults are employed to prepare the answers for their students. Parents rejoice when their children or wards come home with unmerited results or certificates internal or external (Edukugho, 2006). Principals and teachers are no longer interested in the quality of education given to student preparation to face examination challenge. Infact, teachers turn the staff rooms into business centres where commodities are sold and bought. They have the confidence that the children will be assisted to pass their exams. Supervisors, invigilators and the security agents also compromise these fraudulent and unethical acts. The students are no more committed to their academic work. These and many other factors have eroded the Nigerian educational system. The standard of education in Nigeria has fallen. This is as a result of the involvement at all levels of education in the examination fraud. The goal of national educational system and indeed national development becomes a mirage if examination ethics is not encouraged and instituted (Maheshwari, 2011). How can the educational system in our society be prevented from total collapse? At this point this paper is considered timely and very important. Secondary school students cheat in various forms, example, micro-chip popularly known as "chukuli", giraffe (elongation of the neck), sorting, ECOMOG / ECOWAS / OAU, computer, the contraction system (exchange of question paper with already prepared answer scripts), super-print system, impersonation (employing a bright person to write the examination in place of weak students) and host of other forms of examination malpractice.

Examination malpractice have taken a new dimension in Nigeria such as buying questions and marks including teachers and examiners, supersvisors and invigilator assisting students to write examination, arbitrary award of marks, cheating, sneaking maps, graphs, charts, data answered scripts, specimen, textbooks and drawing into the examination hall etc. The deplorable situations in Nigeria assessment practice calls for urgent solution.

Peer pressure becomes a very crucial variable when determining factors that facilitate attitude of secondary school students towards examination malpractice. Judy et'al (2002) stated that peer pressure emerges as a potential factor in the adolescent transitional period from childhood to adulthood. They went further to report that peers become more influential in the life of adolescents and dependent on their peers. The pressure to conform to the standards of the group has a strong impact on the behaviour of the adolescents. Komolafe (2004) reported that adolescence period is the stage when adolescent confide in their peers and spend most of their time with them. He referred to the age as the age of terrible teens. Santrock (2006) refer to it as the age of identity, independence and autonomy. There is strong affiliation and attachment of adolescents to their peers. Wikipedia (2010) reporting Sutherland theory stipulates that criminals learn criminal and deviant behaviour from the interactions between individuals and groups and not inherent in the individuals nature. Most of the student's involvements in examination malpractice were most times pressure from their peers. Oak 
(C2002-2009) observed that peer pressure is the phenomenon individuals (mostly adolescence) get influenced by the life style and thinking pattern of others.

Peer pressure is described as influence exerted by a peer group to make individuals (adolescents) to change their attitudes, values, behaviour in order to conform to group norms. Wikipedia (2010), Matthew (C2003 - 2010) and Oak (2002- 2009) emphasised that peer pressure has much impact on adolescent's behaviour than any other factor. They also further observed that adolescent interaction with their peers is direct and much more powerful than the influence of counsellors, teachers and other authority figures. The teenagers spend much of their waking hours with peers than with family members. Wikipedia (2010), Oak(c2002-2009), Mathew (C2003-2010) noted that peer pressure have both negative and positive impact on the attitude of adolescent towards examination malpractice. The growing menace of examination malpractice in our schools is becoming worrisome and disturbing phenomenon. Olushola (2006) noted in his research that peer pressure as an environmental factors is capable of influencing students attitude toward examination malpractice positively or negatively.

Blay (2007) noted that "if students took their studies seriously and learn hard they would be preparing adequately to write and pass examination to avoid examination malpractice or cheating" she added that "Examination is a despicable vice which need to be uprooted completely from our society" she appealed to the students to be disciplined and make good use of their time to study in order to excel in their examinations and their chosen careers" she advice them against peer pressure, all forms of indolence and lackadaisical attitude towards studies because it makes student to be prone to undertaking acts leading to examination malpractice.

Peer pressure is bound to affect most adolescents (secondary school students) positively or negatively. Peer pressure may make an adolescent do what he never wanted to do, lead negative lifestyle and loss of individuality(Oak C2002-2009). Wikipedia( 2010) reported Bruce A. Epstein theory on how to combat negative peer pressure earlier cited in the September 2002 issue of current health 2, A weekly reader publication as " the desire to be accepted by their peers is perhaps the strongest motivating force during adolescence period'. He further gave an instance, of a student who knew the correct answer to a question gave the wrong answer just because everyone else in the class responded wrongly. The consequence of the negative impact of peer pressure is very grievous. Just as Manahar (C2000 - 2009, rightly puts it, " no matter what form it comes peer pressure erodes the individuality of the child and retards personal growth". Even, Manahar emphasising on the negative effect of peer pressure stated that it kills individuality and gives rise to a set of people who are merely clones of each other. Moreover, he claimed that the loss of individuality can be the biggest setback anyone can suffer in his or her entire life.

Ogidefa, (2008) reported the research findings of Ezewu and Pai (1982) which revealed that academic aspiration of the school child is positively related to the socio-economic status of his parents. Ogidefa, stressed that mostly parents impose their children some courses which the society value or accord high repute, example law, medicine, accounting, engineering etc. 
Admission requirements for those courses require credit passes at $\mathrm{O}$ level. In an attempt to help the children get credit passes, some parents will go all length to buy live papers or lavish the invigilators with gift.

Khan and khan (2011) examined an association between socio-economic status of student and malpractices in secondary school certificate (SSC) examination in urban areas of district of Pechawar. It was found that there was relationship between cheating and students' educational level and siblings, where as cheating was independent of students age, fathers education and occupation parents' income level, mothers' education and mothers status (working woman or house woman)

\section{Gender and Students Attitude to Examination Malpractice}

The study determined the predictive power of gender on the students' attitude to examination malpractice. Judy et'al (2002) reported study in which he compared the level of moral development of delinquent boys. He found that the delinquent boys reasoned largely, at the preconvention level (low level of moral development and maturity) while the non delinquent boys reasoned at conventional level (high level of moral development and maturity). They reported Browfield and Thompson (1984) research which measured the relationship between self-reported delinquency and peer delinquency in a sample of white males. They found a significant positive relationship between the two. Abdulrazaq and Salmanl (2008), who investigated the views of female students about the causes and solutions to examination malpractice, However, results indicated societal preference for paper qualification, inadequate preparation for examination, lack of self confidence, ill equipped schools, lack of good study habits and host of others were considered as the causes of examination malpractice.

The Delta State Ministry of Education took some drastic measures in curbing examination malpractice. Delta State Ministry of Education in their handbook on 2006 Annual Report: the crusade against examination malpractice reported that she is not relenting in her effort to curb the hydra-headed monster examination malpractice. In her war against examination malpractice various measures were employed. For example:

1) Compilation of names of candidates and schools suspected to have been involved in the malpractice to various examination bodies for sanctions.

2) The investigation of teachers and principals suspected to have aided and abetted examination malpractice, and a host of other measures.

It is interesting to note that the numerous measures employed could not do much in curbing the vices. It is then imperative to examine one major theory that counsellors can employ in curbing the vices to a large extent. Moral development theory can be employed by school counsellors in resolving the problem of examination malpractice. Kohlberg (1984) work extensively on the theory of moral development which referred to as the "Heinz dilemma". The Heinz dilemma theory was based on interview held with some young people to 
determine the reasoning behind their judgement or actions. Kohlberg for instance, presented Heinz dilemma or scenario. In this scenario, Heinz's wife was ill with 'cancer' to a point of death. Heinz wanted to procure medicine for the treatment with his little resources. The money he had at that time was not sufficient to purchase the medicine. The chemist could not grant him credit facility. (Kolhberg asked " should Heinz allow his wife to die or break into the store and steal the medicine for his wife's treatment?(Kolhberg, 1984). The question requires critical reasoning or thinking before responding emotionally, Heinz would not want his wife to die. Considering the societal, norms and values he would not steal He can employ other sources to increase his resources to treat his wife.

Judy et'al (2002) presented the cognitive developmental tradition which is of the view that " a person's level of moral development affects the ability to resist the temptation to behave immorally'. They agree with Schulman (1989) that behaviour can be considered moral if adhere to the normative standards of the situation at hand. Judy et'al reported Piaget and Kolhberg study on how moral reasoning, and moral maturity could be developed in individuals and proposed processes by which moral decision are made. According to them, the criteria which guide moral decision and actions are based on fear of punishment, personal gains, consideration of societal needs, respect for authority and law, universal moral principles and human rights. Considering the immerse contributions of moral Education school, counsellors, should encourage and promote acquisition of positive moral skills in the school children.

Okorodudu, (2006) supported the idea of giving moral training to the school children through inculcation of the following values:

- Promoting achievement of improved reorientation towards societal justice. This would help in resolving social justice and or inequality in the society.

- Promoting self control and self discipline would reduce or remove fraud, bribery, dishonesty etc.

- Promoting positive work and attitude.

- Promoting meaningful courage for positive decision making.

- Promote courage or boldness to identify with what the society consider right or wrong.

The school counsellor can employ the following steps in developing positive moral skills in the school children:

Use of punishment or the threat of it.

i. Giving rewards for manifestation of good moral acts.

ii. Encouraging emulation of good conducts or behaviour shown by peer groups

iii. Facilitating positive reflexive thinking on moral demand of society as a guide to one's behaviour in and out of school setting (Okorodudu, 2006.) 


\section{Method}

\subsection{Study Overview}

The study adopted a survey approach in investigating the relationship between peer pressure and the attitude of secondary school students toward the examination malpractice. This is an expost facto research. The independent variables in the study (peer pressure, socio-economic status and gender) determined the nature and existence of relationships between them and the dependent variable (students' attitude toward examination malpractice).

\subsection{Population and Sampling Process}

The Junior Secondary School 2 students constituted the population of the study. The sample size of 1000 participants comprising male and female and participants from low and high socio-economic background were drawn from public secondary schools in Delta State of Nigeria. 618 males which is $62 \%$ and $38 \%$ females participants were used for the study. The total numbers of participants were selected through multi stage and simple random sampling technique

\section{Measures}

The study investigated the relationship between the independent variables (peer pressure, socio-economic status and gender) and dependent variable (student attitude towards examination malpractice). The items were designed base on Kohlberg scenario that increases critical reasoning (Kohlberg, 1984). Responses of 100 participants were used to establish the psychometric properties of the instrument. The instrument was in two parts. Part one comprised the demographic information of the participants (example: gender). Part two of the instrument had three sub units or sections: Section A consists of eleven item statements on students' attitude to examination malpractice. The content and construct validity of the instrument was established using the factor analytical method: Content validity of .64alpha level was achieved. This is an indication of high content validity, out of 20 item forwarded, 12 items were obtained. The selection process involved choosing items having factor matrix between .50 and above. Item with rotated factor matrix below .50 were eliminated as not showing much evidence of exam malpractice syndrome (Turnage and Sielberger, 1991 and Vagg and spielberger 1998). Psychometrically, for example items 1-12 which measured this variable, had factor rotated matrix of $.84, .64, .69, .66, .73, .65, .80, .55, .71, .50, .70, .79$ respectively. These high alphas were suggestive of construct validity. Two examples of the items are: students writing exams should use the answers dictated by the invigilator to answer their exam questions. Students who went blank in the exam should copy from their best friends sitting close to them. An alpha reliability co-efficient estimate of .77 was obtained using cronbach's alpha based method.

Section B contained 21 items statement. The content and construct validity was established using factor analytic method some peer pressure items were adapted from Otuadah, 2006 on peer pressure. The co-efficient alpha of $.62, \mathrm{P}<.05$ level of significance was obtained. The 
content validity was established using extraction method, principal component analysis. This is suggestive of high content validity. The construct validity was established. 21 items were presented for factor rotated component matrix analysis. The selection process involves choosing items having rotated factor matrix between 50 and above. Items with rotated factor matrix below .50 were eliminated as not having evidence of peer pressure. For example, item 1-21, which measured peer pressure, had factor matrixes of $.72, .78, .67, .59, .67, .74, .65, .61, .60, .52, .53, .73, .84, .72, .73,65, .80,71, .52, .67, .58$. The peer pressure factor matrixes stated above is an indication of high construct validity. Three examples of items that measured peer pressure were: I have friends who engage in stealing behaviour, I obey my friends' instruction; I love to always be with my friends. The selected items were used to determine the predictive power of peer pressure on students' attitude towards examination malpractice. In the study on alpha co-efficient reliability value of .92, $(\mathrm{P}<.05)$ level of significance was obtained. These are suggestive of high internal constituency and stability of the instrument (Onocha and Okpala, 1995).

Section C consisted of 11 item statements on participant's socio-economic background. The content and construct validity was established using factor analytic method. The content validity of the instrument was established using the extraction method: principal component analysis. The alpha value of $.56 \mathrm{P}<.05$ was obtained. This is an indication of high content validity. However, construct validity was established in the study. Out of 13 items forwarded for rotated factor matrix, 11 items show evidence of socio-economic traits. For instance, items 1-10 which measured this variable had rotated factor matrix of $.84, .65, .86, .52, .88, .65, .75, .55, .55, .55$. These items were used to measure the socio-economic status if the participants. The following are to examples in the section: I have text books for all my school subjects, I go to school without pocket money sometimes. The section had reliability index of $.73, \mathrm{P}<.05$ value using cronbach alpha method. These are suggestive of high internal consistency and stability of the instrument used in the study. The items were scored based on the Likert four point scale measurement ranging from $\mathrm{SA}=$ strongly agree, $\mathrm{A}=$ agree, $\mathrm{D}=$ disagree and $\mathrm{SD}=$ strongly disagree. The options on the instrument were weighted In the Likert format. Negative items attracted low scores while positive items high scores. For example $\mathrm{SA}=4, \mathrm{~A}=3, \mathrm{D}=2, \mathrm{SD}=4$ for rating positive items using both positively and negatively worded items is one of the ways bias can be reduced. This is by designing items that are phrased in opposite directions (Spector, 1992).

\section{Procedure}

The study investigated the relationship between peer pressure and students' attitude to examination malpractice. The estimate of 1100 copies of the questionnaire was distributed to junior secondary school 2 students in Delta South Senatorial district. 1000 copies of the questionnaire were retrieved. The items retrieved, scored and calculated by summing the participant responses on each section of the part 2 of the instrument. The data from the dependent variables (peer pressure, socio-economic status and gender) used to regress against the data collated from dependent variable (student attitude towards examination malpractice 
Aremu, 2006). Four research four questions and three research hypotheses were formulated for the purpose of the study.

\section{Analysis}

The nature of the relationship that exists among all the variables was determined using correlations matrix analysis. The relative contributions of the predictors to the criterion (students' attitudes towards examination malpractice) were determined. Similarly the effect of the predictors on the independent variable (SAE) was also investigated using simple regression analysis statistic.

\section{Results}

The outcome of the study presented on the matrix table showed correlation between peer pressure and students' attitude to examination malpractice. Table 1 show the result of the nature of the relationship of all the variables investigated in the study. Table 2 showed the result of the simple regression and analysis of variance to answer research $\mathrm{H} 01-\mathrm{H} 03$.

H01: Simple regression analysis on peer pressure (pp) and students' attitude to examination malpractice (SAE) $\mathrm{R}^{2}$ of $.223, \mathrm{P}<.05$ and $\mathrm{R}^{2}$ adjusted of $.222, \mathrm{P}<.05$ level of confidence which is statically translated to $22.3 \%$ effect size or contribution of the total variance. The analysis of variance on the effect of the predictor $(\mathrm{pp})$ to SAE of participation yielded $\mathrm{f}$ of 286.07, $\mathrm{df}=1 / 998, \mathrm{P}<.05$ level of confidence. The result shows significant relationship. This is an indication that PP is a good predictor of SAE. The result further suggested the peer pressure is one of the major factors that enhance examination malpractice behaviour among students.

H02: simple regression analysis on socio-economic status and student attitude to examination malpractice had $\mathrm{R}^{2}$ of $.001, \mathrm{P}>.05$ and $\mathrm{R}^{2}$ adjusted as $.00, \mathrm{P}>.05$ level of significance. The above result statistically translates to $00.0 \%$ contribution of the total variance. The analysis of variance on the effect of the predictor (SES) on SAE of the of the participants showed $\mathrm{F}$ of .80, df of 1/997, P> .05 level of relationship between SES and SAE of the participants in the study. This result suggested that the rate of involvement in the examination malpractice does not depend largely on socio-economic status. This means that both children of poor and the rich are involve in the malpractice. This is suggestive of the fact that been male or female has nothing to do with examination malpractice. This goes on to show that both male and female participates widely in the vice.

H03: simple regression analysis was conducted on the gender and students attitude to examination malpractice (SAE). The result indicated that $\mathrm{R}^{2}$ of $.00, \mathrm{P}>.05$ level of significance which statistically translate to mean $00 \%$ effect size. The analysis of variance on the effect of the students' attitude to examination malpractice yielded F of 2.22, df of 1/998, p>.05 level of significance. This showed no significant relationship between gender and students attitude to examination malpractice (SAE). 


\section{Macrothink}

Table 3 also showed the result of the relative contribution of the predictors to the students' attitude to examination malpractice. The result of standardised Bs and t-test of the predictors were reported to this table. It is of note worth, that APA task force on statistical influence urged researchers to always provide some effect size estimate when reporting a $\mathrm{P}$ value, failure to report effect size is a defect in the design and reporting of researchers. The table consisting of the result are presented below. It should be noted that reporting non significant results are as important as significant result (Kline 2005).

Table 1: Correlation Matrix of Predictor Variables on Students' Attitude to Examination Malpractice

\begin{tabular}{lcccccc}
\hline Variable & 1 & 2 & 3 & 4 & $\mathrm{M}$ & $\mathrm{SD}$ \\
\hline Gender & - & .05 & -.03 & -.02 & .63 & .48 \\
SAE & & - & .03 & $.47^{* *}$ & 52.04 & 9.67 \\
SES & & & - & .06 & 33.23 & 27.59 \\
PP & & & & & & \\
\hline
\end{tabular}

Note: * correlation is significant at $\mathrm{P}<.05$ (2 tailed)

** Correlation is significant at $\mathrm{P}<.01$ (2 tailed)

Pp correlated SAE at the alpha of $.47^{* *}, \mathrm{P}<.01, \mathrm{M}$ score of 52.04 and SD of 9.67

Table 2: Simple Regression Analysis of Factors Predicting Students' Attitude Towards Examination Malpractice

\begin{tabular}{|c|c|c|c|c|c|c|c|c|c|c|}
\hline Source & Df & SS & MS & $\mathrm{B}$ & SEB & $\mathrm{R}$ & $\mathrm{R}^{2}$ & $\mathrm{R}^{2}$ adjusted & $\mathrm{F}$ & $\mathrm{P}$ \\
\hline PP Regression & 1 & 20791.67 & 20791.67 & .47 & .02 & .22 & .22 & .22 & .000 & \\
\hline Residual & 998 & 72536.39 & 72.68 & & & & & & & \\
\hline SES Regression & 1 & 74.69 & 74.694 & .03 & .01 & .03 & .00 & .00 & .80 & .37 \\
\hline Residual & 998 & 93252.37 & 93.44 & & & & & & & \\
\hline Gender Regression & 1 & 207.45 & 207.45 & .05 & .63 & .05 & .00 & .00 & 2.22 & .14 \\
\hline Residual & 988 & 93120.62 & 93.31 & & & & & & & \\
\hline
\end{tabular}

Note: $\mathrm{R}=.47=40 \%, \mathrm{R}^{2}=.223=22.3 \%, \mathrm{R}^{2}$ adjusted $=.222=22.2 \%, \mathrm{~F}=286.07, \mathrm{P}<.05$ 
Table 3: Table Showing Relative Contributions of the Predictors to Students' Attitude to Examination Malpractice

\begin{tabular}{llllll}
\hline VARIABLE & $\mathrm{B}$ & $\mathrm{SEB}$ & $\mathrm{B}$ & $\mathrm{t}$ & $\mathrm{P}$ \\
\hline Constant & 26.01 & 1.55 & & 16.89 & .000 \\
PP & .39 & .02 & .47 & 16.91 & .000 \\
Constant & 51.71 & .48 & & 107.20 & .000 \\
SES & .01 & .01 & .03 & .89 & .37 \\
Constant & 51.46 & .50 & & 103.16 & .000 \\
Gender & .94 & .63 & .05 & 1.49 & .146 \\
\hline
\end{tabular}

Interestingly, the result above showed that peer pressure highly predicted students' attitude to examination malpractice. This revelation is suggestive of the fact that reduction in the effect of peer pressure will reduce negative examination behaviour among secondary school students. The regression line drawn showed increasing predictive power of the peers on the participants at the study. Description of events and their relationships often provide basis for prediction (shaughnessy, and Zechmeister, 2003).

\section{Discussion of Results}

The study to the best of Researcher's knowledge is the first to examine the effect of peer pressure, socio-economic status and gender on students' attitude to examination malpractice in Nigeria. Serious effect was made to draw conclusions and inferences from the research findings. The research finding will grant the school counsellors the understanding and clearance on how examination malpractice problem can be solved. The current study also created basis upon which moral development theory can be employed to solve the problem of examination fraud. The study establishes a strong relationship between peer pressure and students' attitude to examination malpractice in the school setting.

\section{STUDY 1}

Peer pressure versus students' examination malpractice the outcome of this study revealed that strong relationship exists between peer pressure and students' attitude to examination behaviour. The implication of this finding showed that peer influence has a very strong hold on attitude of secondary school students to assessment practices. The finding is supported by Wikipedia (2010) theory of "structural functionalism". This school of thought claimed that individual's commits crime for the good of an individual's group, for the self due to or justified by lack of ties or because the societal norms that place the individual in check no longer have power due to society's corruption. Wikipedia also presented another theory which is in line with findings of the current study. This is Robert K. Merton's theory of anomie/strain.

This theory described a state in which social goals and the legitimate means of achieving them do not correspond. The outcome of the current study is in line with Judy et'al, 2002. They claimed that Peer pressure is a potential factor in the adolescents (secondary school 
student) transitional period from childhood to adulthood. This becomes more influential in the life of the adolescent. Komolafe (2000) agreed that the adolescent period is the age of "terrible teens". He also observed that adolescent spends more time with their peers than family members. Santrock (2006) refers to this as the age when adolescents have strong affiliation and attachment with their peers. Wikipedia (2010) reported Sutherland theory which stipulates that criminals learn criminal and deviant behaviour through interaction with other individuals and groups, not inherent in the individuals' nature. Oak (C2002 - 2009) observed that peer pressure is a phenomenon that gets individuals influenced by other peoples' lifestyles and thinking pattern. Peer pressure is defined as influence exerted on somebody to bring about a change in attitude, values or behaviour in order to conform to group norms. Wikipedia and Matthew (C2003 - 2010) observed that peer pressure has more impact on adolescent behaviour than any other factor. Oak (C2002 - 2009) observed that adolescent desire to be accepted by their peers is the strongest motivating factor. Manahar (C2000 - 2009) observed that negative effect of peer pressure kills individuality and gives rise to a set of people who are merely clones to each other. Aderogba (2011) listed causes of examination malpractice to include Laziness, poverty, pride, peer influence, desire for paper qualifications etc. Ibukun el'tal (2011); Olushola(2006); Blay (2007) and Olatunbosun (2009) agreed that peer pressure is a major factor that influencies student's attitude towards examination malpractice in Nigeria.

\section{STUDY 2}

The outcome of the study 2 revealed no significant relationship between socio-economic status and students' attitude to examination behaviour. This finding is not congruent with the study of (Ogidefa, 2008). He stated that academic aspiration of the school child is positively related to the socio-economic status of parents. This current finding further explains why children from high and low socio-economic status perpetuate this great evil.

\section{STUDY 3}

Another factor considered in this current study is gender of the participants. The outcome of the study showed no significant relationship. This is contrary to the work of (Judy et'al, 2002 and Abdurazaq et'al). Judy et'al worked on the levels of moral development of delinquent and not delinquent boys using Kohlberg theory. Their findings revealed delinquent boys reasoned at preconvention level (low level of moral development and maturity). Non delinquent boys reasoned at conventional level (high level of moral development and maturity). They also reported Browfield and Thompson research findings which measured the relationship between self reported delinquency and peer delinquency among a sample of white males. This finding discovered positive relationship between the two. Indeed the study had revealed that examination behaviour has something to do with peer pressure of the participants/students at the secondary school level not considering whether the student is from low or high socio-economic background or male or female. 


\section{Implications for Couselling}

This research has implications for secondary school students counselling. The outcome of the study clearly revealed that relationship exists between peer pressure and examination behaviour of students. The peer influence may have negative or positive impact or both on the students. First, the school counsellor should help student to reduce the negative impacts of peer pressure through the use of counselling skills. Second, in addressing the issue of examination malpractice the school should not consider whether the student is male or female or from high socio-economic background. Third, the study advocated the use of moral education principles in developing good sense of judgement and decision making.

\section{References}

Abdlrazaq Olayinka Oniye and Aminullahi Salman (2006). Female students perceived causes of and solution to examination malpractice in the ASA local Government implication for counselling. Sokoto Educational Review, 10(2). Retrieved from www.unilorin.edu.ng/unilorin/publication/oniye/FEMALE

Aderogba, K.A. (2011). Examination Malpractice in schools and colleges of Ifo. Educational zone: implications for sustainable educational development, 1(3), 130-148. Retrieved from www.journals.savap.org.pkp

Aremu, Oyesoji (2006). A confluence of credenting career experience, self-efficacy, emotional intelligence, and motivation on the carrier commitment of young police in Ibadan. Nigeria policing: an international journal of police strategies and management, 28(4), 609-619. http://dx.doi.org/10.1108/13639510510628695

Blay, R. (2007). Study hard to avoid examination malpractices; a speech presented on the fifth speech and prize-giving day of the odoben senior high school at odoben in the asikuma-odoben-brakwa district of the central region on Saturday, 11- Novermber 2007.

Brownfield, D., \& Thompson, k. (1991). Attachment to the peer and delinquent behaviour. Canadian Journal of criminology, 33(1), 45-60.

Edukugho, Emmanuel (2006, Wednesday, 2nd January, vanguard). Issues that will shape educational system.

Federal Ministry of Education (NPE 2008) section pp.

http://en.wikipedia.org/wiki/peerpressu retrieval date 29-06-2010

Ibukun, W.O., \& Oyewole, B.K (2011). Examine examination malpractices in Nigerian schools: environmental influences and management strategies, international journal of Business and management tomorrow 1(2); 1-7.

Ivor, Ogidefa. (2008). Exam malpractice in Educational Institutions in Nigeria, Implications for the counsellors. 
Jekayinfa, A. (undated). Curbing examination dishonesty through values in university of Ilorin.

www.Unilorin.edu.ng/---/14\%20Book\%20CURBING\%20EXAMINATION\%20DISHO NEST\%---

Judy Beth \& Eileen S. Nelson (2002). Relationship between parents, peers, Morality, and Theft in an adolescent sample. James H. Mcmillan and Jon F. Wergin (Ed); Understanding and Evaluating Educational Research (2 ${ }^{\text {nd }}$ edition), PP.52-64

Khan. I., \& khan. M.J. (2011). Socio-economic status of students and malpractices used in Examinations in urban areas of district Peshawar. European Journal of scientific research, 49(4), 601-609.

Kline, Rex B. (2005). Beyond Significance Testing Reforming Data Analysis Method in Behavioural Research. Washington D.C, American Psychological Association.

Kolhberg, (1984). The Philosophy of Moral Development, Moral States and the Idea of Justice. New York; Hasper and Row Publishers.

Komolafe, A.M. (2000). Managing Adolescent Crime through Drama. In. I. A. Nwazuoke, Yemisi Bamgbose; O.A. Morokola (Ed); Contemporary Issues and Researches on Adolescents, pp. 54-71

Maheshwari, V.K (2011). Malpractice in examination- The Termites Destroying the Educational set up: philosophical commentary on issues of today; 24-11-2011.

Manhar, Uttara (C2000 - 2009). Effect of Peer Pressure http://www.buzzle.com/articles/effects-of-peer-pressure.html Retrieved 6-05-2010

Matthew, F. (C2003 - 2010). Peer pressure Retrieved from http://www.wisegeek.com/what-is-peer pressure.htm 6-05-2010

Ministry of Education (2006). Rules and Regulations Guiding the Conduct of Internal and External Examinations in Delta state of Nigeria.

Ministry of Education (2006). The crusade Against Examination Malpractice: Delta State Annual Report.

Oak Monali (C2002 - 2009). Negative and Positive Effects of Peer Pressure. Retrieved 6-05-2010. Retrieved from www.buzzle.com/artist/negative-and-positive-effects-of-peer-pressure.html

Okorodudu, R. I. (2006, $2^{\text {nd }}$ edition). Education and Reorientation for Good citizenship in Nation Building. Counselling Psychological approach. Benin City, Justice Jeco printers.

Olatunbosun, J.B (2009) Examination malpractice in secondary schools in Nigeria: what sustains it? European Journal of Education studies, 1(3), 101-108. Ozelacademy.com/EJESVIN3-1.pdf.

Onacha, C.O., \& Okpala, P. N. (1995). Tools for Educational research. Jattu- Uzarue,Edo 
State: Stiking - Hotrden publishers (Nig.) Ltd.

Santrock, J.W. (2006). Human Adjustment. New York: Mcgraw Hill Companies Inc.

Schulman, M. (1989). The prevention of antisocial Behaviour through Moral Motivation training, or why isn't there more street crime? Prevention in Human Services, 7(1), 255-263. http://dx.doi.org/10.1300/J293v07n01_12

Spector, Paul E. (1992). Summated Rating Scale Construction: An Introduction, Series: Quantitative Applications in the social sciences. California, Sage Publications Inc.

Thompson, Bruce. (2006). Foundation of Behavioural Statistic: An Insight-based Approach. New York: (the Guilford Press).

Turnage, J.J., \& Speilberger, C.D. (1991). Job stress in managers, Professional, Clerical Workers. Journal of Work and Stress, 5(3), 163-176.

Unknown authority peer pressure (undated) Retrieved from http://www.aspeneducation.com/factsheetpeerpressure.html retrieved 6-05-2010

Vagg, P.R., \& Speilberger, C. D. (1998). Occupational Stress Measuring Job Pressure and Organisational support in the Work Place. Journal of Occupational Health Psychology, 13(4), 294-305. http://dx.doi.org/10.1037/1076-8998.3.4.294

Wikipedia (Modified 21 June 2010). Peer Pressure.

\section{Copyright Disclaimer}

Copyright reserved by the author(s).

This article is an open-access article distributed under the terms and conditions of the Creative Commons Attribution license (http://creativecommons.org/licenses/by/3.0/). 